\title{
Investigating the Efficacy of an Intensive English Program and the L2 Learners' Learning Styles
}

\author{
Rebecca Lee Su Ping \\ Swinburne University of Technology \\ Sarawak Campus \\ Jalan Simpang Tiga \\ 93350 Kuching, Sarawak \\ E-mail: rlee@swinburne.edu.my
}

Doi:10.7575/aiac.alls.v.5n.6p.246
URL: http://dx.doi.org/10.7575/aiac.alls.v.5n.6p.246
Received: 07/09/2014

Accepted: 03/11/2014

\begin{abstract}
Past research has found that many pre-university L2 learners, having completed an Intensive English Program (IEP) still have difficulty in undertaking various disciplines in English-speaking tertiary institutions and continue to exhibit numerous linguistic problems (Bialystok, 2001, Celce Murcia 2001). The purpose of this paper is to present the findings on the investigation of L2 learners' English proficiency in reading, writing, grammar, listening and speaking upon their completion of an Intensive English (IE) program using their IELTS (Academic), in-house exams and English Placement Tests (EPT) scores, and the efficacy of IE program. IELTS test is chosen for this study due to its increasing popularity in Malaysia and its internationally recognised value and quality. The study was conducted in two parts. In Part One, all 72 Level 4 IE students were given an in-house EPT (English Placement Test) pre-test on their entry and another EPT post-test on their exit, and then their pre-test and post-test results were compared. In Part Two, 22 volunteers sat the IELTS test at the end of the program. The IELTS results of the 22 volunteers were compared with those who did not. Data were analyzed using both quantitative and qualitative methods. This paper hopes to shed some light on (i) whether or not L2 learners' English language proficiency can be significantly enhanced and influenced by an intensive English program and (ii) how leaners' perception of their own learning strategies influence their learning progress.
\end{abstract}

Keywords: Intensive English program, learning strategies, language proficiency

\section{Introduction}

The Intensive English Program at SUTS (Swinburne University of Technology, Sarawak Campus) is a 10-week course designed to accelerate students' English competency at various proficiency levels so that they will be ready for undergraduate or postgraduate studies after completing the required level(s).

\subsection{SUTS Intensive English Program (IEP)}

SUT IEP which began in 2005 as a single-unit single-level course has since developed into a six-level course as follows:

- $\quad$ Level 1: Basic Intensive English (BIE)

- Level 2: Pre-Intermediate Intensive English (PIIE)

- Level 3: Intermediate Intensive English (IIE)

- Level 4: Upper Intermediate Intensive English (UIIE)

- Level 5: Advanced Intensive English (AIE)

- Level 6: English for Postgraduate Students (EPS)

The program is designed to give L2 learners the maximum interactive learning and most intensive practice in listening, speaking, reading, writing, vocabulary and grammar. Each level runs for 10 weeks and comprises 200 hours of learning in the classroom, language laboratory and library. It covers General English and English for Academic Purposes.

Throughout the program, students are given training in employing reading strategies, using standard grammatical rules, writing and proofreading different text types. They are also given the opportunity to improve their listening skills and spoken English through various communication and application activities, which include individual presentations, group discussions, short drama skits, roleplaying, interviews and so forth.

\subsubsection{Extra-curricular Activities}

In order to encourage students to interact with lecturers, mingle with peers of various cultural and linguistic backgrounds and practice using English in stimulating and creative ways, extra-curricular activities organized by 
lecturers and various clubs are provided throughout the program. Students are expected to actively involve in program events and activities as follows:

- Team building and ice-breaking activities

- Language games and activities

- Jungle trekking and other outdoor activities

- Language workshops

- Music, dance and drama

All activities are conducted on campus except for jungle trekking in which students are brought to a nearby jungle trekking facility to have a nature walk. On weeks not highlighted above, afternoon tutorials were given to students where students had the opportunity to meet their various unit lecturers for language support.

\subsubsection{Aims and Objective of the program}

At the end of the program the students are expected to have acquired the necessary grammar, a wider academic vocabulary, a better comprehension of academic text, coherent writing of academic text, confidence in speaking English, improved oral fluency and accuracy, and ability to understand spoken English.

\subsection{Related literature}

The nature of Intensive English (IE) programs are commonly recognised as accelerated, time-shortened, compressed, flexible and alternative (Scott \& Conrad, 1992; Wodkowski, 2003) whereby the length of class time as well as the number of classes are condensed in a shorter period compared to non-intensive or traditional courses. There are many different definitions and distinctions in the literature on accelerated education or intensive program according to Tatum (2010). Sometimes, the educational process is sped up or compressed, altering the total contact hours of traditional semesters or structures while there are times when the total contact hours in the classroom is reduced in order to create an intensive learning environment for fast tracking specific learning modules. In this study, the intensive English course compresses reading, writing, grammar, listening and speaking into 10 weeks of study (4 hours per skills and 20 hours in total a week) which aims to help fast track Second Language (L2) learners' acquisition of English as a Second Language (ELS) in the shortest possible time so that their transition from school to university studies will be smoother.

There are both positive and negative implications on the learners' learning. On a more positive note, Hong-Name and Leavell (2006) suggests that Intensive English Program (IEP) is an important step in developing both the students' Basic Interpersonal Communications Skill (BICS) and their Cognitive Academic Language Proficiency (CALP). It has also been mentioned in several studies (Burton \& Nesible, 2002; Scott and Conrad, 1991; Daniel, 2000) that L2 learners' motivation, commitment and engagement increase when courses are conducted intensively as many L2 learners find such courses more challenging, stimulating, effective, exciting and enjoyable.

However, from the psychological point of views, Henbery (1997) argued that apart from not being able to digest compressed materials and condensed knowledge, they usually feel more tired, stressful and frustrated in an intensive program. Since literature on intensive English courses suggests inconsistencies in the effectiveness of such programs, further research in this area is needed.

There are many psychological dimensions such as the cognitive, emotional and social aspects relating to accelerated or intensive learning according to Tatum (2010); however, the main focus of this study to investigate the achievement of the learners who have undergone the 10-week intensive learning environment.

\subsection{Objective and Research Questions}

The study sets out to investigate the efficacy of an Intensive English Program and the L2 learners' learning styles during the 10-week Intensive English Program by aiming to answer the following research questions:

1. Does the 10-week Intensive English Program have any significant impact on the L2 learners' learning progress?

2. Do the students' learning styles affect their learning progress?

\section{Methodology}

\subsection{Instruments}

The following instruments were used for this study:

The in-house English Placement Test (EPT) was administered free of charge to 72 Level 4 students at the beginning and end of a 10-week study period. The purpose of the pre and post-tests was to gauge score differences over time. Although it is was not possible to administer the same test version to all the students and to synchronize the pre and post-tests, both versions were equated in terms of level of difficult, types of questions and format.

The IELTS (Academic) test was administered to 22 Level 4 students who volunteered to sit the test at the end of a 10-week program. The purpose of the test was to benchmark its score differences with EPT test scores in order to determine the validity of the EPT tests used in the pre and post-test sessions. IELTS test, a high stakes selection test, has been recognised worldwide as a reliable measure of candidates' English language proficiency to study at a tertiary institution. Unlike EPT, IELTS is made up of 
four different subtests: Listening, Reading, Writing and Speaking. At the end of the test, each candidate receives a test report which indicates a band score of between 0 and 9 for each sub-test and an overall score which is the average of these results. The minimum score required by a tertiary institution is Band 6 or Band 6.5 for undergraduate study and Band 7 for postgraduate study.

Semi-structured interviews with a set of the Level 4 students on a voluntary basis were conducted at the post-test session. The interview questions built around the students' learning styles, experience and perception of the program - what they did to improve themselves in the language, what they liked most and least about the program, what and how much they have improved, what or who motivated them, what strategies they used to cope with the intensive nature of the course and what was their best experience during the course. The purpose of the interview was to find out the feedback of the students on their learning styles, experience and the possible reasons of the progress (or lack thereof) during the 10-week period.

\subsection{Administrative Procedures}

It was a simple and straightforward study involving all the 72 Level 4 students in Term 1 . All the students were given the same treatment before, during and after the program. They were given one EPT test by the recruitment officers in the Exam Unit on an on-going basis at different times and dates before they were enrolled into the program. Exam officers and EPT markers were not aware of which students were taking the test for research purposes. Once the students were enrolled into Level 4, the exit level to foundation courses, the researcher recorded all the students' results at the Exam Unit. During the program, students were given the same treatment - being taught the same methods and materials in a class of 25 students over the 10 -week period. At the end of Week 10 and right before their final IE exams, the students were asked to sit another EPT test (the post-test) to ensure adequate participation as it was feared that students would disperse immediately after their last papers and would not care to sit the posttest. Similarly, students were asked to sit the IELTS test in Week 10 voluntarily. However, due to the financial constraints, only 24 students responded and their results were sent to the researcher who had subsidized the test partially using limited seed grant funding.

\subsection{Validity Constraints}

In this study, there were a few constraints. First of all, there was inevitably some attrition over the 10 -week period, with a number of students who presented at the pre-test session failing to show up for the post-test for various unknown reasons. Those who did turn up for the test were not all motivated and did not attempt all the questions as they should have done in their final exam. Some, however, used the test as a practice opportunity and gave their best shot.

Another constraint was that the EPT only consisted of reading, grammar and writing without listening and speaking. The writing Task 1 in EPT required students to give a written response to a non-linear text which was not part of the Level 4 writing syllabus so many students would not have any idea how to answer the question. Non-linear text is only taught in Level 5 onward. Therefore, it might have some impact on the validity and reliability of the writing data. The only reliable source of the students' English language proficiency (in terms of listening, speaking, reading and writing) was the IELTS test scores of the 24 students who volunteered to sit the test.

It is also important to mention that the timing of the interview proved to be somewhat problematic as many students were not interested in giving elaborated response on their language learning experiences when all the exams were over. Only a handful of students gave a detailed oral feedback to the interviewer.

\section{Results}

Data were analyzed using both quantitative and qualitative methods. The results revealed that students made variable progress in English during the 10-week period with $95 \%$ of them made an average again of 0.5 band. The greatest gains were in listening, whereas the grammar skills were less improved.

Another source of data for this study was the interviews. The triangulation process made by analyzing findings from all interviews conducted. Maxwell's (1992) conceptualization of validity theory was used to further understand what was said and how it was interpreted.

Research question 1: Does the 10-week Intensive English Program have any significant impact on the L2 learners' proficiency?

The results of this study show that there was a significant difference in 72 learners' proficiency between the pre-test and post-test scores $[\mathrm{t}(3)=3.2, \mathrm{p}=.046<.05]$ at the end of the 10-week Intensive English program and the mean scores (Mean difference $=9$ ) differ significantly as indicated in Table 2. Since there were real score gain in the post-test, the study revealed that L2 learners had made substantial achievement in post-test compared to their performance in the pre-test, supporting the findings of Ligthbrown and Spada (1994) and Raymond (1995, cited in Jacques-Bilodea, 2010) where students' language proficiency improved significantly after taking intensive English programs.

Worthy of note is that those who joined the Intensive English Program with lower initial scores actually made higher percentage of achievement than those who came with a higher initial score in the post-test. Among the three skills reading, writing and grammar - being tested in both pre-and post-tests, the greatest gains were in reading (Table 3), followed by writing, whereas grammar skills were somewhat less amendable to improvement. 
Table 1. Comparison between pre test and post test scores

Paired Samples Test

\begin{tabular}{|c|c|c|c|c|c|c|c|c|}
\hline & \multicolumn{5}{|c|}{ Paired Differences } & \multirow[b]{3}{*}{$\mathrm{t}$} & \multirow[b]{3}{*}{ df } & \multirow[b]{3}{*}{ Sig. (2-tailed) } \\
\hline & \multirow[b]{2}{*}{ Mean } & \multirow[b]{2}{*}{ Std. Deviation } & \multirow{2}{*}{$\begin{array}{l}\text { Std. Error } \\
\text { Mean }\end{array}$} & \multicolumn{2}{|c|}{$\begin{array}{l}95 \% \text { Confidence } \\
\text { Interval of the } \\
\text { Difference }\end{array}$} & & & \\
\hline & & & & Lower & Upper & & & \\
\hline PRE_TEST - POST_TES & -8.58500 & 5.23443 & 2.61722 & -16.91415 & -.25585 & -3.280 & 3 & .046 \\
\hline
\end{tabular}

Table 2. Overall gains in the pre-test and post-test

Paired Samples Statistics

\begin{tabular}{|c|c|c|c|c|c|}
\hline & & Mean & $\mathrm{N}$ & Std. Deviation & $\begin{array}{l}\text { Std. Error } \\
\text { Mean }\end{array}$ \\
\hline Pair & PRE TEST & 10.6500 & $\overline{4}$ & 7.14545 & 3.57273 \\
\hline 1 & POST_TES & 19.2350 & 4 & 11.95791 & 5.97895 \\
\hline
\end{tabular}

Table 3. Skills with greatest gains and lowest gains

\begin{tabular}{|l|r|r|r|r|}
\multicolumn{7}{l|}{ One-Sample Statistics } \\
\hline & $\mathrm{N}$ & Mean & Std. Deviation & $\begin{array}{c}\text { Std. Error } \\
\text { Mean }\end{array}$ \\
\hline READING_IMPR & 72 & 7.6458 & 6.04294 & .71217 \\
WRITNG_IMPR & 72 & 4.8028 & 7.48326 & .88191 \\
GRAMMAR_IMPR & 72 & .8861 & 3.55244 & .41866 \\
\hline
\end{tabular}

From the Table 4 below, all students in general showed most improvement in reading skills in terms of score which increased in the post-test followed by writing and subsequently grammar skills.

All the students performed differently during their post-test but there was a significant difference at $95 \%$ confidence level in their improvement with the most difference in their scores obtained was indicated to be in writing skills followed by reading and lastly grammar skills.

Out of the 72 students investigated, $91.78 \%$ of the students showed distinct improvement in reading skills in post-test as compared to pre-test, which was the highest rate of improvement. This was followed by $75.34 \%$ of the students who showed improvement in grammar skills and lastly only $69.86 \%$ of the students showed improvement in writing skills.

Table 4. Skills with overall highest and lowest improvement

One-Sample Test



Table 5 shows that the 22 students who voluntarily sat the IELTS did better in the IELTS than in the Post-test with the mean difference of 16.7. This could mean that the IELTS was comparatively easier than the post-test administered to the students or it could be that the students did not take the post-test seriously after completing their IELTS test.

Table 5. Overall gains in both Post-test and IELTS

\begin{tabular}{|c|c|c|c|c|}
\hline & Mean & $\mathrm{N}$ & Std. Deviation & $\begin{array}{l}\text { Std. Error } \\
\text { Mean }\end{array}$ \\
\hline Pair 1 POST_TEST & 39.6818 & 22 & 15.41455 & 3.28639 \\
\hline IELTS & 56.3105 & 22 & 5.97038 & 1.27289 \\
\hline
\end{tabular}


Tables 6 to 9 further show that the readings scores, when compared in both tests, had no significant difference, meaning that the level of difficult was similar in both tests; however, there was a significant difference in the writing scores, with most of them scores higher in the IELTS writing than in the post-test writing. A check on the students' answer scripts revealed that most of them did not complete their Writing Task 1 and when asked during the interview sessions, they reported that the task was too difficult and some of them decided to give it up without making any reasonable attempt.

Table $6 \&$ Table 7. Comparison between post test and IELTS in terms of reading scores

Paired Samples Statistics

\begin{tabular}{|ll|c|r|r|r|}
\hline & & & & Std. Error \\
& & Mean & N & Std. Deviation & \multicolumn{1}{c|}{ Mean } \\
\hline Pair & POST_READING & 16.4091 & 22 & 4.99198 & 1.06429 \\
1 & IELTS_READING & 16.2132 & 22 & 1.72068 & .36685 \\
\hline
\end{tabular}

Paired Samples Test

\begin{tabular}{|c|c|c|c|c|c|c|c|c|c|}
\hline & \multicolumn{5}{|c|}{ Paired Differences } & \multirow[b]{3}{*}{$\mathrm{t}$} & \multirow[b]{3}{*}{ df } & \multirow[b]{3}{*}{ Sig. (2-tailed) } \\
\hline & & \multirow[b]{2}{*}{ Mean } & \multirow[b]{2}{*}{ Std. Deviation } & \multirow{2}{*}{$\begin{array}{c}\text { Std. Error } \\
\text { Mean }\end{array}$} & \multicolumn{2}{|c|}{$\begin{array}{l}\text { 95\% Confidence } \\
\text { Interval of the } \\
\text { Difference }\end{array}$} & & & \\
\hline & & & & & Lower & Upper & & & \\
\hline $\begin{array}{l}\text { Pair } \\
1\end{array}$ & $\begin{array}{l}\text { POST_READING - } \\
\text { IELTS_READING }\end{array}$ & .19591 & 4.58014 & .97649 & -1.83481 & 2.22663 & .201 & 21 & .843 \\
\hline
\end{tabular}

Table 8 \&Table 9. Comparison between post test and IELTS in terms of writing scores

\begin{tabular}{|ll|l|r|r|c|}
\hline \multicolumn{1}{|c|}{ Paired Samples Statistics } \\
\hline & & Mean & N & Std. Deviation & $\begin{array}{c}\text { Std. Error } \\
\text { Mean }\end{array}$ \\
\hline Pair & POST_WRITING & 16.0455 & 22 & 10.25614 & 2.18662 \\
1 & IELTS_WRITING & 25.0005 & 22 & 4.99988 & 1.06598 \\
\hline
\end{tabular}

Paired Samples Test

\begin{tabular}{|c|c|c|c|c|c|c|c|c|c|}
\hline & & \multicolumn{5}{|c|}{ Paired Differences } & \multirow[b]{3}{*}{$\mathrm{t}$} & \multirow[b]{3}{*}{ df } & \multirow[b]{3}{*}{ Sig. (2-tailed) } \\
\hline & & \multirow[b]{2}{*}{ Mean } & \multirow[b]{2}{*}{ Std. Deviation } & \multirow{2}{*}{$\begin{array}{l}\text { Std. Error } \\
\text { Mean }\end{array}$} & \multicolumn{2}{|c|}{$\begin{array}{l}95 \% \text { Confidence } \\
\text { Interval of the } \\
\text { Difference }\end{array}$} & & & \\
\hline & & & & & Lower & Upper & & & \\
\hline $\begin{array}{l}\text { Pair } \\
1\end{array}$ & $\begin{array}{l}\text { POST_WRITING - } \\
\text { IELTS_WRITING }\end{array}$ & -8.95500 & 7.57688 & 1.61540 & -12.31440 & -5.59560 & -5.544 & 21 & .000 \\
\hline
\end{tabular}

Research question 2: Does the students' learning styles affect their learning progress?

\section{Interview with Sumo}

The first interviewed students has been named Sumo. He was aged 20 at the commencement of the study and had just come to Kuching on a scholarship program. After taking the EPT test, he was enrolled into IE Level 1 as he only scored 4 out of 100 (IELTS Band 0). He could not write and neither could he speak, write or spell anything right. His store of English vocabulary was almost zero. When interviewed, he said he never spoke English at home or back in his country. Ever since he came to the university, he only liked to make friends with students from the same country of origin. He studied, lived, cooked, travelled and socialized with peers from Oman only. Even in class, he preferred to sit with another Omani student. He took 6 terms (60 weeks) to move from the lowest IE level (Level 1) to the higher level IE (Level 4), failing two terms - once in Level 3 and another in Level 4.

When interviewed, he claimed that he found the lecturers helpful and kind, and enjoyed learning from them. In class and after class, he tried his best to learn new vocabulary, memorize the grammar rules and complete all his homework. However, he reported that he did not like to talk to his classmates especially from Malaysia as he could not understand the way they talked even though he had been studying here for more than one and a half years.

Sumo liked the Intensive English program and enjoyed the class and afternoon activities. However, he admitted that he was a reserved and quiet student by nature and did not have many friends on campus.

I like my lecturers and my Omani friends here but I really could not understand Malaysian English. Their pronunciation is so hard to understand so I have give[n] it up. I hope I can make more friends in Australia when I go there next month. 
He had decided to go to Australia to further his studies as he believed he would be happier there. Despite the fact that Sumo scored negatively on the IELTS test (an overall band score of 5), he was very pleased with his progress, knowing that he was from Band zero when he first joined the program.

\begin{tabular}{|c|c|c|c|c|}
\hline Listening & Reading & Writing & Speaking & Overall band Score \\
\hline 5.0 & 5.0 & 4.5 & 6.0 & 5.0 \\
\hline
\end{tabular}

\section{Interview with Kris}

Kris is 34 years old and worked as an IT analyst in Russia for 10 years before coming to Kuching with his wife and his 2 -year-old son. He graduated from a university in Russia with a degree in Computer Science and his proficiency level was below the mean (30 out of 100), starting the program at Level 3. During the interview, he reported that he enjoyed listening to English songs, watching English movies, hanging out with new international and local friends he had met even since he came to Kuching 20 weeks ago. He was very sociable, outspoken and always had a positive outlook of life. He attributed his success to all his lecturers and most importantly - his own initiative and motivation.

I have improved a lot especially speaking and listening. I think it's because I am never afraid to speak to anyone I meet on campus and outside the university. I make friends with my Malaysian classmates, my neighbours and even people I met on a tour. I love to speak English and want to learn as much as I can while I am here. I want my little boy to know that his father can speak and write English well.

However, he admitted that he was still slow in reading and writing as he lacked the necessary vocabulary and speed. Although he had a lot of ideas, he found it hard to express them in writing using the correct words and spelling. Overall, he was very pleased with his results and impressed with the program which he said was the best he had ever attended. He scored Band 6 in the IELTS test and was very proud of his own achievement. He intended to undertake another degree in IT after coming back to Kuching from Russia with his family in two to three months' time.

\begin{tabular}{|c|c|c|c|c|}
\hline Listening & Reading & Writing & Speaking & Overall band Score \\
\hline 6.0 & 5.5 & 5.5 & 7.0 & 6.0 \\
\hline
\end{tabular}

\section{Interview with Kim}

Kim is a 40-year-old married man from Korea. He has three children aged 5, 7 and 9. Both he and his wife came to Kuching to learn English together with their children. He had studied English in Korea for many years and his proficiency level at the beginning of the study was above the mean (60 out of 100). He had been working as a social worker in the Philippines for 4 years before he came to Kuching. He liked the intensive English program in this university but found it too intensive with classes back to back on top of the afternoon workshops and activities that he needed to attend. He spent a big chunk of his time with his wife and his children every day so he had little time to make friends with other students. In order to improve his test scores, he spent a lot of time doing revision after class whenever he could and had never failed to hand in his assignments. His lecturers described him as a highly-dedicated student who was constant trying his best to improve all areas of his English. However, he reported that listening and writing were difficult for him as he lacked the vocabulary and was slow at catching the words and phrases in oral settings. He had always wanted to study Master in TESL but felt devastated when he received Band 6 instead of Band 7 even though he had tried very hard to improve his English.

\begin{tabular}{|c|c|c|c|c|}
\hline Listening & Reading & Writing & Speaking & Overall band Score \\
\hline 5.5 & 6.0 & 5.5 & 6.5 & 6.0 \\
\hline
\end{tabular}

\section{Discussion \& Implications}

The findings emerging from this study are both positive and encouraging and that the 10-week intensive study at SUTS does make a significant difference with $95 \%$ of the students showing improvement in English in the quantitative data, moving up half a band in the reading and speaking components especially. Though some may argue that a score gain in itself does not always mean a real gain in language proficiency or the degree of improvement for each individual student may vary or even fall short of what is expected, one important implication is that L2 learners' English language proficiency can be significantly enhanced and influenced by an intensive English program which Bruner (1960) calls - a "spiral curriculum", where each topic is presented and built on the previous one sequentially in smaller units (accelerated classes), creating the spiral effects in language transfer. |In fact, research prior to 1992 found no differences between intensive courses and traditional courses (Ray \& Kirkpatrick, 1983). However, Geltner and Logan (2001) showed positive results for the intensive courses they investigated. They found that the students in their studies had a higher success rate and better average grades in shorter language courses (6- 8 weeks) compared to longer courses (16 weeks). Jonas and Weimer (1999) also had similar results when the business students' scores in both an intensive program and a traditional (non-intensive) program were compared. It was found that the 124 intensive students scored 
higher on the Educational Testing Service's Major Field Achievement Test than the 209 students in the traditional program. Nevertheless, it is unclear if the findings of this study conducted in an English-medium university of an English-speaking country can be generalized to other contexts. It would be worth to conduct experimental studies which include learners with and without exposure to English outside the classroom in different formats (an intensive program and a traditional program) to determine the instructional effectiveness of an intensive program. Furthermore, the findings will be more accurate if the study is to be carried out across levels (Level 1 - Level 6) longitudinally for a period of 5 terms, instead of the current 1-term and -1level study.

Another important finding is that the extent of L2 learner's improvement does not depend solely on their initial scores. Some researchers like Weissberg and Stuve (1979) reported that students entering an intensive English program with higher initial scores will presumably do better than those who enter the program with lower initial scores. Although similar views were shared by Nevo, Sim and Bensousan (1977) who commented that the gains of intensive English to be "The rich get richer and the poor stay poor", it is not necessary the case and the common assumption that scores on a standardized proficiency test can serve to identify individuals is arguable. The results of this study revealed contrasting results, indicating that students with lower initial scores actually had higher percentage of improvement. Similar results were obtained among tenth year English language students in a Swedish university where generally students with higher entering scores on a proficiency test made greater gains on the same test a year later than did students with lower initial scores (Marton, 1972).

According to Skehan (1989), language aptitude was found to be the most influential quality of a successful language learner. Other learning strategies and styles that differentiate successful learners and less successful learners were also discussed extensively in Good Language Learner studies of Naiman, Fohlich, Stern and Todesco (1987). Ellis (1994), for example, claimed that effective learners attend to form and meaning, show awareness in the learning process, involve themselves in the language learning tasks as well as assess their needs and evaluate progress constantly. Although from the quantitative aspect of the study, there is no indication of what had actually enhanced or impeded learners' progress, it seemed that motivation and social influence are the two important learning strategies which could have a great impact on L2 learner's learning which were transpired through the interviews with the students. Take for an example, Kris was a more successful learner compared to Kim, and Sumo who was the least successful learner. Kris was always keen to learn. He not only focused on the formal classroom learning, but also in the informal learning environment in which English learning can be further developed. However, many students like Sumo and Kim did not have the initiative or did not see the importance of developing relationships with students from other nationalities both inside and outside the classroom as an important learning strategy. Focusing too heavily on formal and conscious aspects of learning in language classrooms or by trying their best to memorize all the inputs they received in the classrooms might not yield the expected return as in Kim's case.

In any intensive program, learners need to have high level of initiative and motivation which does not only come from the learners themselves but also from their peers. According to Landtolf (2000) and Norton $(1995,2000)$, successful language learners have the ability to best exploit their learning and social environments. It is therefore important to note that in order to improve in the language in an intensive program setting, firstly, motivation of the learners is foremost important. Secondly, learner should not focus too heavily on formal and conscious learning in the classroom at the expense of social influences. In Kris' case, he seized the opportunity of building friendships with students from various nationalities both inside and outside the classroom. In other words, being socially accepted by peers is highly significant for the learner to improve the language as it builds up his confidence and his attitude to learn. Thus, study on the importance of language contact outside the classroom compared to language received in the classroom should warrant further investigation.

\section{Conclusion}

The purpose of this study was to investigate the effectiveness of the intensive English program and the learners' learning strategies and the results which clearly indicated the high percentage of improvement had been encouraging. Overall the SUTS Intensive English Program (IEP) can be considered successful in enhancing L2 learners' English proficiency, but a re-examination of the test instruments and the timing of the tests as well as taking into consideration of their test scores over the period of time and or a longitudinal study across levels should be employed. There are, however, two limitations of the study. For one, the IELTS, a high stake test, was only taken by 22 students instead of all 72 students as at the post-test session. The results would have been clearer and more accurate if the IELTS were administered to all 72 students before and after the intensive English program. Secondly, the in-house Entrance Placement Test especially the writing section was seemingly too difficult for all students, resulting in students not making any attempt in Task 1 and affecting their overall performance in both the pre-test and post-test. Thirdly, the study should be carried out longitudinally across the levels for a minimum period of 1 year (4 terms) to ensure more precise and accurate results. Other than that, this paper has shed some light on whether or not L2 learners' English language proficiency can be significantly enhanced and influenced by (i) an intensive English program and (ii) appropriate learning strategies.

\section{References}

Austin, A. M., \& Gustafson, L. (2006). Impact of course length on student learning. Retrieved on July 25, 2012, from http://www.economics-finance.org/jefe/econ/Gustafsonpaper.pdf

Bruner, J. (1960). The process of education. Cambridge, MA: Harvard University Press. 
Burton, S., \& Nesbit, P. (2002). An analysis of student and faculty attitude to intensive teaching. Paper presented at the celebrating teaching and Macquire, Macquire University.

Daniel, E.L (2000). A review of time-shortened courses across disciplines. College Student Journal, 34, 298-308.

Ellis, R. (1994). The study of second language acquisition. Oxford: Oxford University Press.

Gallow, M.A., \& Odu, M. (2009). Examining the relationship between class scheduling and student achievement in college algebra. Community College Review, 36(4), 299-325.

Geltner, P., \& Logan, R. (2001). The influence of term length on student success. Research Report 2001. 4.1.0. Santa Monica, CA: Office of Institutional Research, Santa Monica College.

Henbery, K. (1997). The impact of class schedule on student performance in a financial management course. Journal of Education for Business, 73(2), 114.

Hong-Nam, K., \& Leavell, A.G. (2006). Language learning strategy use of ESL students in an intensive English learning context. Science Direct: Eleisever, System 34 (2006) 399-415.

Jacques-Bilodeau, M.(2010). Research project: A study of the long term effects of Intensive English programs on secondary school ESL students. Retrieved on 23 August, 2014, from www.csbe.qc.ca/projetrd/doc_projet/marie_jac_bil_2010.pdf

Jonas, P. M., \& Weimer, D. (1999, May-June). Non-traditional vs. traditional academic delivery systems: Comparing ETS scores for undergraduate students in business programs. Paper presented at the Forum of the association for Institutional Research. Seattle, WA.

Mukundan, J., Mahvelati, E.H., \& Nimehchisalem, V. (2012). The effect of an intensive English program on Malaysian secondary school students' language proficiency. English Language Teaching; Vol. 5, No. 11.

Marton, F. (1972). The tenth year of English: A review of a project concerning second language learning at university level. Higher Education, 1, 93-109.

Nagano, T. (1995). Nohongo no onsei kyoiku - Supichi komyunikeishon (Japanese oral expression education Speech communication).

Naiman, N. Frohlich, M. Stern, H.H., and A. Todesco (1978). The good language learner. Research in Education Series, 7, Ontario Institute for Studies in Education.

Nevo, Baruch, Donald Sim, and Marsha Bensoussan (1977). The rich get richer and the poor get poorer: A quantitative evaluation of the outcomes of a program for teaching English as a Foreign Language. System, 5 (1), 3337.

Ray, R.E., \& Kirkpatrick, D. R. (1983). Two time formats for teaching human sexuality. Teaching of Psychology, 10, 84-88.

Scott, P.A. (1994). A comparative of students, learning experiences in intensive and semester-length and of the attributes of high-quality intensive and-semester course learning. Paper presented at the Meeting of the North American Association of Summer Sessions Portland.

Scott, P. A., \& Conrad, C.F. (1992). A critique of intensive courses and agenda for research. Madrison WI: Division of Summer Sessions and inter-college programs, university of Wisconsin.

Skehan, P. (1989). Individual differences in second language learning. London: Arnold.

Spradley, J. P. (1979). The ethnographic interview. London: Holt, Reinhart \& Winston.

Spurling, S (2001). Compression of Semesters or Intensity of Study: What is it that increases student success? ERIC Document Reproduction Service, No.ED467474.

Tatum, B.C. (2010). Accelerated education: learning on the fast track. Journal of Research in Innovation Teaching; Vol.3, Issue 1 (March 2010), 33-50.

Weissberg, R. C., \& Stuve, M. (1979). Differential gain rates in intensive ESL programs: Who gains the most? System, Vol. 7. pp. 61-65. Pergamon Press Limited.

Wlodkowski, R.J., Iturralde-Albert, L., \& Mauldin, J. (2000). Report on accelerated learning research project: Phase 4. The center for the Study of Accelerated learning, Regis University, School for Professional Studies and New Ventures, Denver, CO. 